Check for updates

Cite this: RSC Adv., 2018, 8, 2498

12th November 2017

Accepted 21st December 2017

DOI: 10.1039/c7ra12363a

rsc.li/rsc-advances

\section{Novel steroidal saponins with cytotoxic activities from the roots of Ophiopogon japonicus (L. f.) Ker-Gawl $\uparrow$}

\author{
Yan Wu, Su-Xia Bi, + Zhen Huang, Jin Qi* and Bo-Yang Yu (D) *
}

Six new steroidal saponins (1-6) and one known steroidal saponin (7) were obtained from the roots of Ophiopogon japonicus (L. f.) Ker-Gawl. Their structures were determined by the detailed analysis of extensive nuclear magnetic resonance and mass spectroscopic data. The in vitro cytotoxic activities of these compounds against MDA-MB-435, HepG2 and A549 cell lines were also investigated.

\section{Introduction}

Ophiopogon japonicus (L.f.) Ker-Gawl is an evergreen perennial in the family Liliaceae and mainly distributed in the Southern of China, Japan, Vietnam and India. O. japonicas is widely artificially cultivated in Zhejiang and Sichuan Provinces of China. ${ }^{1}$ The tuber of $O$. japonicus, commonly known as Maidong, is a famous herb used to treat coughs, sore throats, constipation and insomnia for thousands of years in Traditional Chinese Medicine. $^{2}$

Pharmacological studies indicated that the tubers of $O$. japonicus exhibit various biological activities such as immunomodulation, anti-diabetes, cardiovascular protection, anti-oxidation and anti-cancer. ${ }^{3-7}$ In recent years, the significant pharmacological effects of the tubers of $O$. japonicus on cardiovascular disease and cancer have drawn much attention from medicinal researchers. Previous phytochemical investigations on the tubers of $O$. japonicas resulted in the isolation of homoisoflavonoids, ${ }^{8-13}$ organic acids, ${ }^{14-16}$ saccharides ${ }^{17,18}$ and steroidal saponins. ${ }^{19-23}$ However, the bioactive ingredients of this herb are still not fully elucidated. As part of our ongoing progress to search for bioactive constituents from traditional Chinese medicine, a 75\% EtOH extract of the roots of $O$. japonicus was investigated which led to the isolation of six new steroidal saponins (1-6) and one known steroidal saponin (7) (Fig. 1). The in vitro cytotoxic activities of these compounds against MDA-MB-435, HepG2 and A549 cell lines were also investigated. In this paper, we describe the isolation, structural elucidation and cytotoxic activities evaluation of these steroidal saponins.

\footnotetext{
Jiangsu Key Laboratory of TCM Evaluation and Translational Research, China Pharmaceutical University, Nanjing 211198, People's Republic of China. E-mail: boyangyu59@163.com; yaoyuelingxing@163.com; Fax: +86-25-86185158; Tel: +8625-86185157

$\dagger$ Electronic supplementary information (ESI) available. See DOI: 10.1039/c7ra12363a

\$ Co-first author.
}

\section{Results and discussion}

The phytochemical investigation of a $75 \% \mathrm{EtOH}$ extract of the roots of Ophiopogon japonicus (L. f.) Ker-Gawl resulted in the isolation of seven steroidal saponins (1-7), including six new steroidal saponins (1-6) and one known steroidal saponin (7). The known compound (7) was identified as (25R)-ruscogenin-1$O$ - $\alpha$-L-rhamnopyranosyl-( $1 \rightarrow 2)$-[ $\beta$-D-xylopyranosyl- $(1 \rightarrow 3)]-\alpha$-Larabinopyranoside by comparison of its $\mathrm{MS},{ }^{1} \mathrm{H}$ NMR and ${ }^{13} \mathrm{C}$ NMR data with published data in the literature. ${ }^{24}$

Compound 1 was isolated as an amorphous solid and gave a positive Liebermann-Burchard reaction. Its molecular formula was assigned to be $\mathrm{C}_{44} \mathrm{H}_{70} \mathrm{O}_{17}$ by the HRESI-QTOF-MS ion peak at $m / z$ 893.4447 $[\mathrm{M}+\mathrm{Na}]^{+}$(calcd for $\mathrm{C}_{44} \mathrm{H}_{70} \mathrm{O}_{17} \mathrm{Na}$, 893.4505). The ${ }^{1} \mathrm{H}$ and ${ }^{13} \mathrm{C}$ spectra of 1 (Tables 1-4) displayed characteristic signals for four steroidal methyl groups $\left[\delta_{\mathrm{H}} 0.68\right.$ $(3 \mathrm{H}, \mathrm{d}, J=4.5 \mathrm{~Hz}), 0.96(3 \mathrm{H}, \mathrm{s}), 1.09(3 \mathrm{H}, \mathrm{s})$ and $1.24(3 \mathrm{H}, \mathrm{d}$, $J=7.0 \mathrm{~Hz})]$, an olefinic group $\left[\delta_{\mathrm{C}} 141.2,122.2 ; \delta_{\mathrm{H}} 5.31(1 \mathrm{H}, \mathrm{d}, J=\right.$ $5.0 \mathrm{~Hz})]$, three anomeric protons $\left[\delta_{\mathrm{H}} 4.92(1 \mathrm{H}, \mathrm{d}, J=7.5 \mathrm{~Hz})\right.$, $5.90(1 \mathrm{H}, \mathrm{d}, J=3.0 \mathrm{~Hz})$ and $6.24(1 \mathrm{H}, \mathrm{br} \mathrm{s})]$ and three anomeric carbon signals at $\delta_{\mathrm{C}} 100.5,111.6,102.4$. These spectra data together with the observation that three anomeric protons signals at $\delta_{\mathrm{H}} 4.92,5.90$ and 6.24 giving correlations with three anomeric carbon signals at $\delta_{\mathrm{C}} 100.5,111.6,102.4$ in the HSQC spectrum, implied that $\mathbf{1}$ was a steroidal derivative containing three sugar units.

The ${ }^{13} \mathrm{C}-\mathrm{NMR}$ chemical shifts at $\delta_{\mathrm{C}} 32.8$ (C-23), 29.2 (C-24), $32.9(\mathrm{C}-25)$ and $67.1(\mathrm{C}-26)$ as well as the characteristic absorptions of a $25(R)$ spiroketal unit at 981, 918, 892, 836 (intensity $918<892 \mathrm{~cm}^{-1}$ ) in the IR spectrum indicated that the C-25 configuration of the aglycone was $R$. The aglycone moiety of 1 was further deduced to be pennogenin by comparison its ${ }^{1} \mathrm{H}$ and ${ }^{13} \mathrm{C}$ NMR data to those reported in the literature. ${ }^{25-27}$ Complete assignments of each sugar unit were achieved by analyses of their chemical shifts and coupling constants obtained from extensive $1 \mathrm{D}$ and $2 \mathrm{D}$ NMR experiments, allowing the identification one $\beta$-glucopyranosyl (Glc), one 

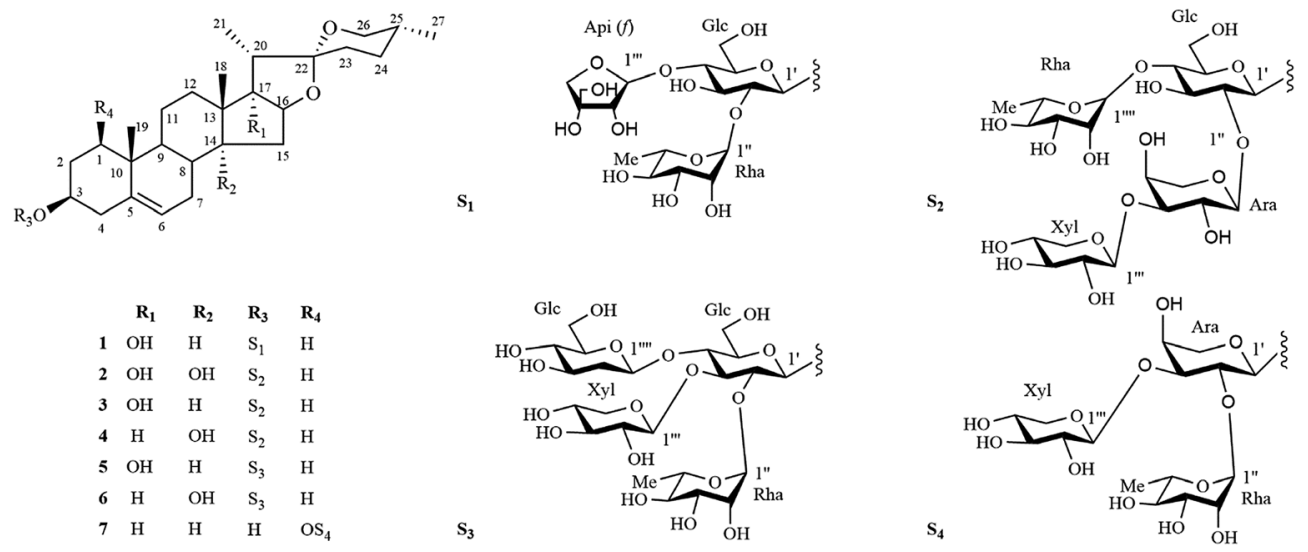

Fig. 1 Chemical structures of compounds 1-7.

Table $1{ }^{13} \mathrm{C}$ NMR data for aglycone moieties of compounds $1-6^{a}(\delta$ in ppm, pyridine- $d_{5}$ )

\begin{tabular}{|c|c|c|c|c|c|c|}
\hline Position & 1 & 2 & 3 & 4 & 5 & 6 \\
\hline 1 & 37.6 & 38.1 & 38.0 & 37.9 & 37.5 & 38.1 \\
\hline 2 & 30.8 & 30.4 & 31.0 & 30.8 & 30.8 & 30.4 \\
\hline 3 & 78.5 & 78.2 & 78.3 & 78.3 & 78.3 & 78.2 \\
\hline 4 & 39.4 & 39.0 & 39.1 & 40.3 & 39.7 & 39.1 \\
\hline 5 & 141.2 & 140.6 & 141.2 & 140.7 & 141.2 & 140.7 \\
\hline 6 & 122.2 & 122.7 & 122.8 & 122.3 & 122.2 & 122.8 \\
\hline 7 & 32.2 & 26.5 & 32.8 & 27.1 & 32.2 & 27.1 \\
\hline 8 & 30.6 & 36.6 & 30.8 & 36.0 & 30.4 & 36.0 \\
\hline 9 & 50.7 & 43.9 & 50.7 & 44.0 & 50.6 & 44.0 \\
\hline 10 & 38.0 & 37.8 & 37.6 & 37.6 & 37.9 & 37.9 \\
\hline 11 & 21.4 & 20.5 & 21.4 & 20.8 & 21.3 & 20.8 \\
\hline 12 & 32.2 & 26.9 & 32.8 & 32.2 & 32.4 & 32.4 \\
\hline 13 & 45.2 & 48.7 & 45.5 & 45.5 & 45.2 & 45.4 \\
\hline 14 & 53.5 & 88.1 & 53.5 & 86.8 & 53.4 & 86.8 \\
\hline 15 & 32.5 & 40.7 & 32.9 & 39.1 & 32.7 & 40.3 \\
\hline 16 & 90.5 & 90.9 & 90.5 & 82.3 & 90.4 & 82.2 \\
\hline 17 & 90.6 & 91.5 & 90.6 & 60.3 & 90.5 & 60.3 \\
\hline 18 & 17.5 & 21.0 & 17.5 & 20.4 & 17.5 & 20.4 \\
\hline 19 & 19.8 & 19.8 & 19.8 & 19.7 & 19.8 & 19.7 \\
\hline 20 & 45.5 & 45.5 & 45.2 & 42.5 & 45.5 & 42.4 \\
\hline 21 & 10.1 & 10.1 & 10.1 & 15.7 & 10.0 & 15.7 \\
\hline 22 & 110.2 & 109.9 & 110.2 & 110.0 & 110.1 & 109.9 \\
\hline 23 & 32.8 & 32.5 & 32.4 & 31.0 & 32.8 & 31.0 \\
\hline 24 & 29.2 & 29.6 & 29.2 & 29.8 & 29.2 & 29.7 \\
\hline 25 & 32.9 & 30.8 & 30.4 & 30.4 & 32.8 & 30.3 \\
\hline 26 & 67.1 & 67.2 & 67.1 & 67.2 & 66.2 & 67.2 \\
\hline 27 & 17.7 & 17.6 & 17.7 & 17.5 & 17.6 & 17.7 \\
\hline
\end{tabular}

${ }^{a}$ NMR data were measured at $500 \mathrm{MHz}$ for ${ }^{1} \mathrm{H}$ and at $125 \mathrm{MHz}$ for ${ }^{13} \mathrm{C}$ in pyridine- $\mathrm{d}_{5}$. Assignments are based on HSQC and HMBC experiments.

$\alpha$-rhamnopyranosyl (Rha) and one $\beta$-apiofuranosyl (Api) units in 1. Their absolute configurations were further determined to be D for Glc/Api and L for Rha by GC comparison of their corresponding trimethylsilylthiazolidine derivatives to the authentic samples prepared in the same procedure. In the HMBC spectrum (Fig. 2), the correlations between $\delta_{\mathrm{H}} 6.24$ (br s, Rha-1") and $\delta_{\mathrm{C}} 78.0\left(\mathrm{Glc}-2^{\prime}\right)$, between $\delta_{\mathrm{H}} 5.90\left(\mathrm{~d}, J=3.0 \mathrm{~Hz}, \mathrm{Api}-1^{\prime \prime \prime}\right)$ and $\delta_{\mathrm{C}}$ $79.8\left(\right.$ Glc- $\left.4^{\prime}\right)$, between $\delta_{\mathrm{H}} 4.92\left(\mathrm{~d}, J=7.5 \mathrm{~Hz}, \mathrm{Glc}-1^{\prime}\right)$ and $\delta_{\mathrm{C}} 78.5$ (Agly C-3), characterized that the sequence of the sugar chain
Table $2{ }^{13} \mathrm{C}$ NMR data for sugar moieties of compounds $1-6^{a}(\delta$ in ppm, pyridine- $d_{5}$ )

\begin{tabular}{|c|c|c|c|c|c|c|}
\hline Position & 1 & 2 & 3 & 4 & 5 & 6 \\
\hline $1^{\prime}-$ Glc- $1^{\prime}$ & 100.5 & 100.2 & 100.3 & 100.3 & 100.3 & 100.3 \\
\hline $2^{\prime}$ & 78.0 & 79.3 & 79.3 & 79.3 & 76.3 & 76.3 \\
\hline $3^{\prime}$ & 77.8 & 74.2 & 74.3 & 74.3 & 80.7 & 80.7 \\
\hline $4^{\prime}$ & 79.8 & 79.4 & 79.4 & 79.4 & 80.7 & 80.7 \\
\hline $5^{\prime}$ & 77.0 & 77.6 & 77.7 & 77.7 & 78.3 & 78.5 \\
\hline $6^{\prime}$ & 61.7 & 61.4 & 61.4 & 61.4 & 62.4 & 62.4 \\
\hline $2^{\prime \prime}-\mathrm{Ara}-1^{\prime \prime}$ & & 103.6 & 103.9 & 103.9 & & \\
\hline $2^{\prime \prime}$ & & 73.5 & 73.6 & 73.6 & & \\
\hline $3^{\prime \prime}$ & & 75.8 & 75.9 & 75.9 & & \\
\hline $4^{\prime \prime}$ & & 71.2 & 71.3 & 71.3 & & \\
\hline $5^{\prime \prime}$ & & 66.4 & 66.5 & 66.5 & & \\
\hline $2^{\prime \prime}-$ Rha- $1^{\prime \prime}$ & 102.4 & & & & 102.5 & 102.5 \\
\hline $2^{\prime \prime}$ & 72.9 & & & & 72.8 & 72.8 \\
\hline $3^{\prime \prime}$ & 73.2 & & & & 72.8 & 72.8 \\
\hline $4^{\prime \prime}$ & 74.6 & & & & 73.8 & 73.9 \\
\hline $5^{\prime \prime}$ & 69.9 & & & & 70.3 & 70.3 \\
\hline $6^{\prime \prime}$ & 19.0 & & & & 19.0 & 19.0 \\
\hline $3^{\prime \prime \prime}$-Api $(f)-1^{\prime \prime \prime}$ & 111.6 & & & & & \\
\hline $2^{\prime \prime \prime}$ & 78.1 & & & & & \\
\hline $3^{\prime \prime \prime}$ & 80.5 & & & & & \\
\hline $4^{\prime \prime \prime}$ & 75.4 & & & & & \\
\hline $5^{\prime \prime \prime}$ & 65.2 & & & & & \\
\hline $3^{\prime \prime \prime}-\mathrm{Xyl}-1^{\prime \prime \prime}$ & & 103.8 & 103.7 & 103.7 & 102.9 & 102.9 \\
\hline $2^{\prime \prime \prime}$ & & 74.2 & 74.3 & 74.3 & 73.8 & 73.1 \\
\hline $3^{\prime \prime \prime}$ & & 77.6 & 77.0 & 77.0 & 78.3 & 78.9 \\
\hline $4^{\prime \prime \prime}$ & & 71.1 & 71.1 & 71.1 & 70.9 & 70.9 \\
\hline $5^{\prime \prime \prime}$ & & 65.8 & 65.9 & 65.9 & 64.8 & 66.2 \\
\hline $4^{\prime \prime \prime \prime}-\mathrm{Rha}-1^{\prime \prime \prime \prime}$ & & 102.9 & 102.9 & 102.9 & & \\
\hline $2^{\prime \prime \prime \prime}$ & & 73.1 & 72.8 & 72.8 & & \\
\hline $3^{\prime \prime \prime \prime \prime}$ & & 73.1 & 73.2 & 73.2 & & \\
\hline $4^{\prime \prime \prime \prime \prime}$ & & 74.3 & 74.4 & 74.4 & & \\
\hline $5^{\prime \prime \prime \prime}$ & & 70.3 & 70.3 & 70.3 & & \\
\hline $6^{\prime \prime \prime \prime}$ & & 19.0 & 19.1 & 19.1 & & \\
\hline $4^{\prime \prime}-$ Glc- $1^{\prime \prime \prime \prime}$ & & & & & 102.9 & 102.9 \\
\hline $2^{\prime \prime \prime \prime}$ & & & & & 74.3 & 74.3 \\
\hline $3^{\prime \prime \prime \prime \prime}$ & & & & & 75.6 & 75.6 \\
\hline $4^{\prime \prime \prime \prime \prime}$ & & & & & 71.1 & 71.1 \\
\hline $5^{\prime \prime \prime \prime}$ & & & & & 77.2 & 77.2 \\
\hline $6^{\prime \prime \prime \prime \prime}$ & & & & & 61.8 & 62.4 \\
\hline
\end{tabular}

${ }^{a}$ NMR data were measured at $500 \mathrm{MHz}$ for ${ }^{1} \mathrm{H}$ and at $125 \mathrm{MHz}$ for ${ }^{13} \mathrm{C}$ in pyridine- $\mathrm{d}_{5}$. Assignments are based on HSQC and HMBC experiments. 
Table $3{ }^{1} \mathrm{H}$ NMR data for aglycone moieties of compounds $1-6^{a}\left(\delta\right.$ in ppm, pyridine $-d_{5}, J$ in $\left.\mathrm{Hz}\right)$

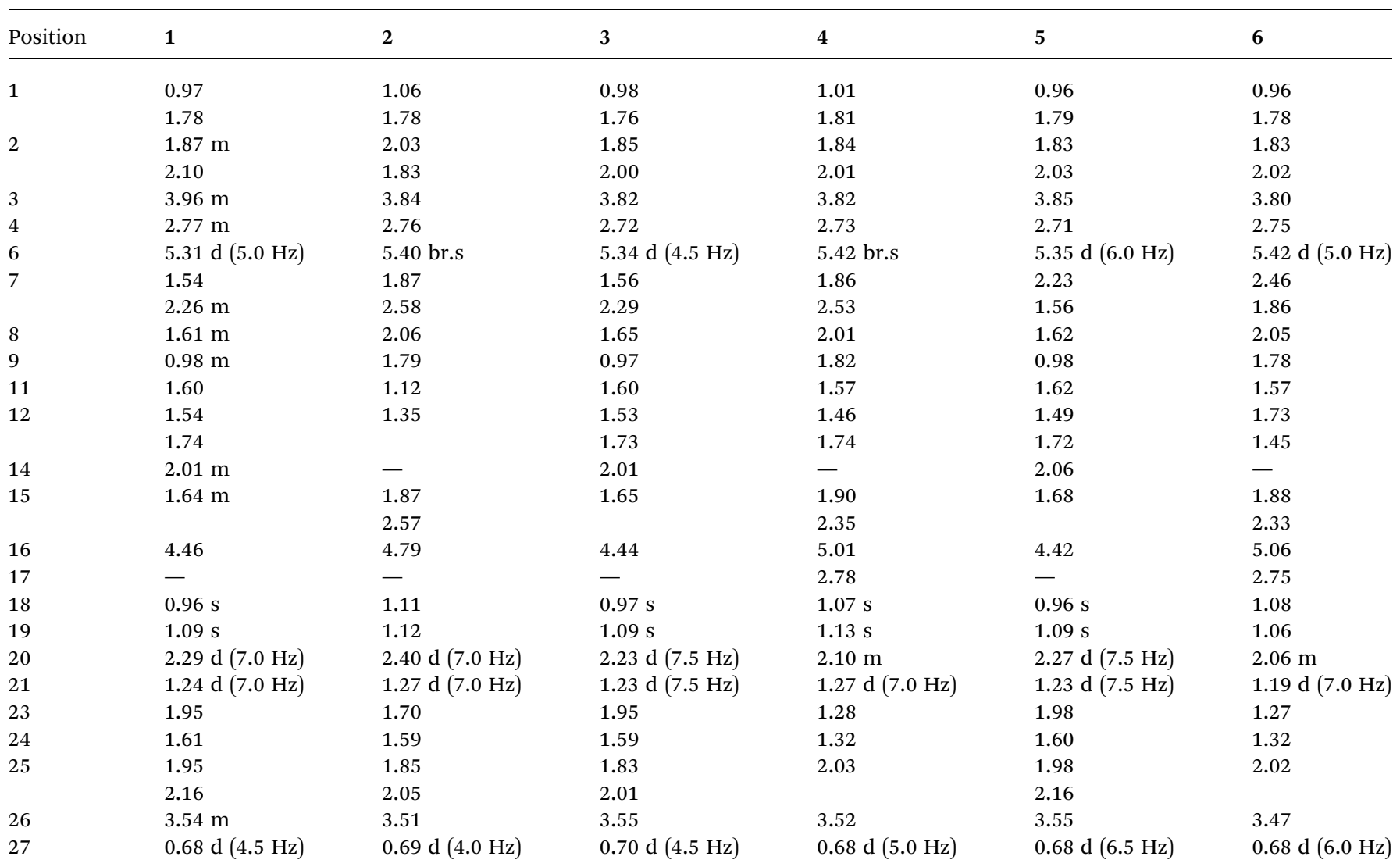

${ }^{a} \mathrm{NMR}$ data were measured at $500 \mathrm{MHz}$ for ${ }^{1} \mathrm{H}$ and at $125 \mathrm{MHz}$ for ${ }^{13} \mathrm{C}$ in pyridine- $\mathrm{d}_{5}$. Assignments are based on HSQC and HMBC experiments.

was $\alpha$-L-Rha- $(1 \rightarrow 2)$-[ $\beta$-D-Api- $(1 \rightarrow 4)]-\beta$-D-Glc, and that the glycosidic site was at C-3. Therefore, the structure of 1 was established as pennogenin-3-O- $\alpha$-L-rhamnopyranosyl-(1 $\rightarrow 2)$ $[\beta$-D-apiofuranosyl- $(1 \rightarrow 4)]-\beta$-D-glucopyranoside.

Compound 2 gave a sodium adduct ion at $m / z 1041.4809[\mathrm{M}+$ $\mathrm{Na}]^{+}$(calcd for $\mathrm{C}_{49} \mathrm{H}_{78} \mathrm{O}_{22} \mathrm{Na}, 1041.4877$ ) in the HRESI-QTOFMS, corresponding to the molecular formula $\mathrm{C}_{49} \mathrm{H}_{78} \mathrm{O}_{22}$. Comparison of the NMR data of 2 obtained from 1D and 2D NMR spectra (Tables 1-4) to those of lirigramoside $\mathrm{A}^{28}$ indicated that their chemical structures were closely similar. The major difference was that the chemical shifts at $\delta_{\mathrm{C}} 32.8$ (C-23), 29.2 (C24), $32.9(\mathrm{C}-25)$ and $67.1(\mathrm{C}-26)$ in the ${ }^{13} \mathrm{C}-\mathrm{NMR}$ spectrum had lower field resonances than those of lirigramoside $\mathrm{A}$, as well as an additional hydroxyl group in the aglycone moiety of 2 . These observations suggested a (25R)-spirostanol aglycone moiety containing three hydroxyl groups for 2 . The aglycone moiety of 2 was further identified as ophiogenin by comparison its spectroscopic data to those reported in the literature. ${ }^{29}$ The HMBC correlations (Fig. 2) between $\delta_{\mathrm{H}} 6.05$ (brs, Rha- $1^{\prime \prime \prime \prime}$ ) and $\delta_{\mathrm{C}} 79.4$ (Glc- $\left.4^{\prime}\right)$, between $\delta_{\mathrm{H}} 5.48\left(\mathrm{~d}, J=5.5 \mathrm{~Hz}, \mathrm{Xyl}-1^{\prime \prime \prime}\right)$ and $\delta_{\mathrm{C}} 75.8$ (Ara$3^{\prime \prime}$ ), between $\delta_{\mathrm{H}} 5.46\left(\mathrm{~d}, J=5.5 \mathrm{~Hz}\right.$, Ara-1 $\left.{ }^{\prime \prime}\right)$ and $\delta_{\mathrm{C}} 79.3$ (Glc-2'), between $\delta_{\mathrm{H}} 4.93\left(\mathrm{~d}, J=7.5 \mathrm{~Hz}, \mathrm{Glc}-1^{\prime}\right)$ and $\delta_{\mathrm{C}} 78.2$ (Agly C-3) indicated 2 contained the same sugar moiety of $\alpha$-L-Rha- $(1 \rightarrow$ $4)$ - $[\beta-\mathrm{D}-\mathrm{Xyl}-(1 \rightarrow 3)-\alpha$-L-Ara( $(1 \rightarrow 2)]-\beta-\mathrm{D}-\mathrm{Glc}$ at C-3 as lirigramoside A. Compound 2 was therefore assigned as ophiopogenin-3-
$O$ - $\alpha$-L-rhamnopyranosyl-(1 $\rightarrow 4)$-[ $\beta$-D-xylopyranosyl-(1 $\rightarrow 3)-\alpha$-Larabinopyranosyl-(1 $\rightarrow 2)]$ - $\beta$-D-glucopyranoside.

Compounds 3 and 4 possessed the same molecular formula $\mathrm{C}_{49} \mathrm{H}_{78} \mathrm{O}_{21}$ as deduced from their HRESI-QTOF-MS data $(\mathrm{m} / \mathrm{z}$ 1025.4871 $[\mathrm{M}+\mathrm{Na}]^{+}$, calcd for $\left.\mathrm{C}_{49} \mathrm{H}_{78} \mathrm{O}_{21} \mathrm{Na}, 1025.4928\right)$. Detailed analysis of their ${ }^{1} \mathrm{H}$ and ${ }^{13} \mathrm{C}$ NMR data (Tables 1-4) suggested that they possessed the same sugar chain at C-3 as 2, but differed slightly in the aglycone moiety. The only difference was the absent of a hydroxyl group in the aglycone moiety of 3 and 4, respectively. The differences in chemical shifts of C-7 $(\Delta \delta$ $+6.3), \mathrm{C}-8(\Delta \delta-5.8), \mathrm{C}-9(\Delta \delta+6.8), \mathrm{C}-12(\Delta \delta+5.9), \mathrm{C}-13(\Delta \delta-$ 3.2), C-14 $(\Delta \delta-34.6)$ and $\mathrm{C}-15(\Delta \delta-7.8)$ observed from comparative analysis of the ${ }^{13} \mathrm{C}$ NMR data of 2 and 3, proved the absent hydroxyl group was attached at C-14 in 2, indicating a pennogenin ${ }^{25-27,30}$ aglycone moiety for 3. Similarly, the differences in chemical shifts of C-12 $(\Delta \delta+5.3), \mathrm{C}-13(\Delta \delta-3.2), \mathrm{C}-14$ $(\Delta \delta-1.3), \mathrm{C}-16(\Delta \delta-7.4), \mathrm{C}-17(\Delta \delta-31.2)$ and $\mathrm{C}-21(\Delta \delta+5.6)$ in the ${ }^{13} \mathrm{C}$ NMR spectra of 4 , compared with those for 2 implied the absent hydroxyl group was at C-17 in 2, the aglycone moiety of 4 was therefore identified to be prazerigenin $A .{ }^{31}$ The structures of the aglycone moiety and the sequence of the sugar chains of $\mathbf{3}$ and $\mathbf{4}$ were further confirmed by the correlations in their HMBC spectrum (Fig. 2). Thus, the structures of 3 and 4 were determined to be pennogenin-3- $O$ - $\alpha$-L-rhamnopyranosy l-(1 $\rightarrow$ 4)-[ $\beta$-D-xylopyranosyl-(1 $\rightarrow 3)$ - $\alpha$-L-arabinopyranoseyl$(1 \rightarrow 2)]-\beta$-D-glucopyranoside and praze rigenin A-3- $O-\alpha$-L- 
Table $4{ }^{1} \mathrm{H}$ NMR data for sugar moieties of compounds $1-6^{a}\left(\delta\right.$ in ppm, pyridine $-d_{5}, \mathrm{~J}$ in $\mathrm{Hz}$ )

\begin{tabular}{|c|c|c|c|c|c|c|}
\hline Position & 1 & 2 & 3 & 4 & 5 & 6 \\
\hline $1^{\prime}-\mathrm{Glc}-1^{\prime}$ & $4.92 \mathrm{~d}(7.5 \mathrm{~Hz})$ & $4.93 \mathrm{~d}(7.5 \mathrm{~Hz})$ & $4.91 \mathrm{~d}(7.5 \mathrm{~Hz})$ & $4.91 \mathrm{~d}(7.0 \mathrm{~Hz})$ & $4.88 \mathrm{~d}(7.5 \mathrm{~Hz})$ & $4.89 \mathrm{~d}(8.0 \mathrm{~Hz})$ \\
\hline $2^{\prime}$ & 4.16 & 4.15 & 4.17 & 4.16 & 4.14 & 4.14 \\
\hline $4^{\prime}$ & 3.85 & 4.51 & 4.52 & 4.52 & 4.68 & 4.64 \\
\hline $5^{\prime}$ & 3.74 & 3.73 & 3.73 & 3.73 & 3.73 & 3.72 \\
\hline $6^{\prime}$ & 4.22 & 4.31 & 4.31 & 4.31 & 4.30 & 4.29 \\
\hline $2^{\prime \prime}$ & & 4.20 & 4.20 & 4.20 & & \\
\hline $3^{\prime \prime}$ & & 4.13 & 4.13 & 4.13 & & \\
\hline $4^{\prime \prime}$ & & 4.12 & 4.13 & 4.13 & & \\
\hline \multirow[t]{2}{*}{$5^{\prime \prime}$} & & 3.67 & 3.67 & 3.67 & & \\
\hline & & 4.52 & 4.52 & 4.52 & & \\
\hline $2^{\prime \prime}$-Rha-1" & 6.24 br.s & & & & 6.23 br.s & 6.21 br.s \\
\hline $6^{\prime \prime}$ & $1.75 \mathrm{~d}(6.5 \mathrm{~Hz})$ & & & & $1.73 \mathrm{~d}(6.5 \mathrm{~Hz})$ & $1.74 \mathrm{~d}(7.0 \mathrm{~Hz})$ \\
\hline $3^{\prime \prime \prime}$-Api $(f)-1^{\prime \prime \prime}$ & $5.90 \mathrm{~d}(3.0 \mathrm{~Hz})$ & & & & & \\
\hline $2^{\prime \prime \prime}$ & 4.74 & & & & & \\
\hline $3^{\prime \prime \prime}$ & 4.18 & & & & & \\
\hline $4^{\prime \prime \prime}$ & 4.30 & & & & & \\
\hline $5^{\prime \prime \prime}$ & 4.13 & & & & & \\
\hline $3^{\prime \prime \prime}-\mathrm{Xyl}-1^{\prime \prime \prime}$ & & $5.48 \mathrm{~d}(5.5 \mathrm{~Hz})$ & $5.49 \mathrm{~d}(5.5 \mathrm{~Hz})$ & $5.48 \mathrm{~d}(6.0 \mathrm{~Hz})$ & $5.51 \mathrm{~d}(6.0 \mathrm{~Hz})$ & $5.50 \mathrm{~d}(6.0 \mathrm{~Hz})$ \\
\hline $2^{\prime \prime \prime}$ & & 4.12 & 4.13 & 4.13 & 4.12 & 4.10 \\
\hline $3^{\prime \prime \prime}$ & & 4.13 & 4.15 & 4.15 & 4.28 & 4.27 \\
\hline \multirow{3}{*}{$\begin{array}{l}4 \\
5^{\prime \prime \prime}\end{array}$} & & 4.13 & 4.13 & 4.13 & 4.16 & 4.12 \\
\hline & & 3.67 & 3.67 & 3.67 & 3.59 & 3.65 \\
\hline & & 4.65 & $4.68 \mathrm{~d}(8.0 \mathrm{~Hz})$ & $4.68 \mathrm{~d}(8.5 \mathrm{~Hz})$ & 4.67 & 4.57 \\
\hline & & & & & 4.11 & 4.02 \\
\hline $3^{\prime \prime \prime \prime}$ & & & & & 4.05 & 4.14 \\
\hline \multirow{2}{*}{$4^{\prime \prime \prime \prime}$} & & & & & 4.20 & 4.19 \\
\hline & & & & & 4.13 & 4.09 \\
\hline $5^{\prime \prime \prime \prime}$ & & & & & 3.83 & 3.80 \\
\hline $6^{\prime \prime \prime \prime}$ & & & & & 4.37 & 4.80 \\
\hline
\end{tabular}

${ }^{a}$ NMR data were measured at $500 \mathrm{MHz}$ for ${ }^{1} \mathrm{H}$ and at $125 \mathrm{MHz}$ for ${ }^{13} \mathrm{C}$ in pyridine- $\mathrm{d}_{5}$. Assignments are based on HSQC and HMBC experiments.

rhamnopyranosyl-(1 $\rightarrow$ 4)-[ $\beta$-D-xylopyranosyl-(1 $\rightarrow 3)$ - $\alpha$-L-arabinopyranosyl-(1 $\rightarrow 2)]$ - $\beta$-D-glucopyranoside, respectively.

The molecular formulas of compounds 5 and $\mathbf{6}$ were established as $\mathrm{C}_{50} \mathrm{H}_{80} \mathrm{O}_{22}$ from their HRESI-QTOF-MS ion peak at $\mathrm{m} / \mathrm{z}$ 1055.4968 (calcd for $\mathrm{C}_{50} \mathrm{H}_{80} \mathrm{O}_{22} \mathrm{Na}, 1055.5033$ ). A comprehensive analysis of the ${ }^{1} \mathrm{H}$ and ${ }^{13} \mathrm{C}$ NMR spectra (Tables 1-4) of 5 disclosed that these data were in good agreement with those of Cixi-ophiopogon B. ${ }^{27}$ The only difference was the absent of a hydroxyl group in the aglycone moiety of $\mathbf{5}$. The aglycone moiety of 5 was further assigned as pennogenin by comparison its ${ }^{1} \mathrm{H}$ and ${ }^{13} \mathrm{C}$ NMR data to those of 3 . In the HMBC spectrum (Fig. 2), the correlations between $\delta_{\mathrm{H}} 6.23$ (brs, Rha- $1^{\prime \prime}$ ) and $\delta_{\mathrm{C}}$ $76.3\left(\mathrm{Glc}^{\prime}\right)$, between $\delta_{\mathrm{H}} 5.51\left(\mathrm{~d}, J=6.0 \mathrm{~Hz}, \mathrm{Xyl}-1^{\prime \prime \prime}\right)$ and $\delta_{\mathrm{C}} 80.7$
(Glc- $\left.3^{\prime}\right)$, between $\delta_{\mathrm{H}} 5.42\left(\mathrm{~d}, J=8.0 \mathrm{~Hz}, \mathrm{Glc}-1^{\prime \prime \prime \prime}\right)$ and $\delta_{\mathrm{C}} 80.7$ (Glc$\left.4^{\prime}\right)$, between $\delta_{\mathrm{H}} 4.88\left(\mathrm{~d}, J=7.5 \mathrm{~Hz}\right.$, Glc- $\left.1^{\prime}\right)$ and $\delta_{\mathrm{C}} 78.3$ (Agly C-3) suggested a $\alpha$-L-Rha- $(1 \rightarrow 2)$-[ $\beta$-D-Xyl- $(1 \rightarrow 3)]$-[ $\beta$-D-Glc- $(1 \rightarrow 4)]$ $\beta$-D-Glc sugar moiety at C-3 for 5 , which was identical to that of Cixi-ophiopogon B. The structure of $\mathbf{5}$ was therefore established to be pennogenin-3- $O-\alpha$-L-rhamnopyranosyl- $(1 \rightarrow 2)-[\beta$-D-xylopyranosyl-(1 $\rightarrow 3)]$-[ $\beta$-D-glucopyranosyl-(1 $\rightarrow 4)]-\beta$-D-glucopyranoside. The aglycone moiety of compound $\mathbf{6}$ was deduced to be prazerigenin A by detailed comparison its NMR data (Tables 14) to those of 4 . Moreover, 6 was established to own the same sugar moiety at C-3 as 5 by the correlations between $\delta_{\mathrm{H}} 6.21$ (brs, Rha- $\left.1^{\prime \prime}\right)$ and $\delta_{\mathrm{C}} 76.3$ (Glc-2'), between $\delta_{\mathrm{H}} 5.50(\mathrm{~d}, J=6.0 \mathrm{~Hz}$, Xyl$\left.1^{\prime \prime \prime}\right)$ and $\delta_{\mathrm{C}} 80.7\left(\mathrm{Glc}-3^{\prime}\right)$, between $\delta_{\mathrm{H}} 5.42\left(\mathrm{~d}, J=8.0 \mathrm{~Hz}, \mathrm{Glc}-1^{\prime \prime \prime \prime}\right)$ 
1

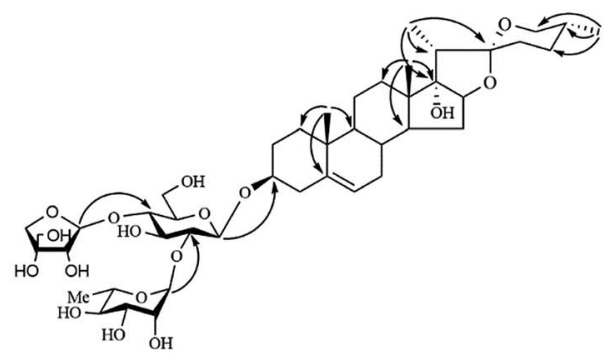

3

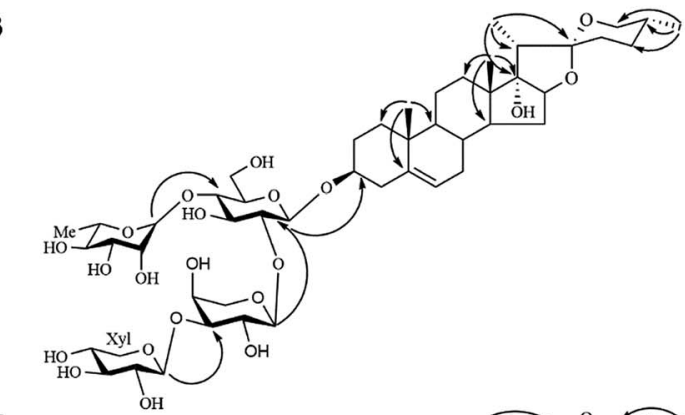

5

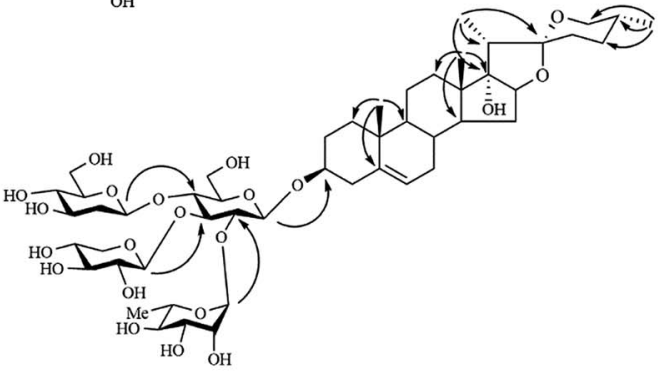

2

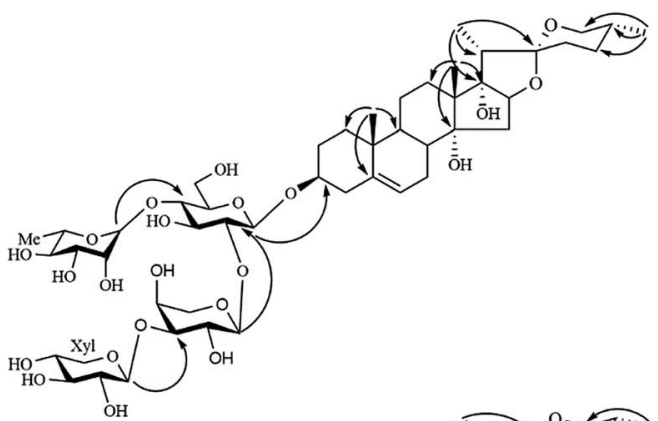

4

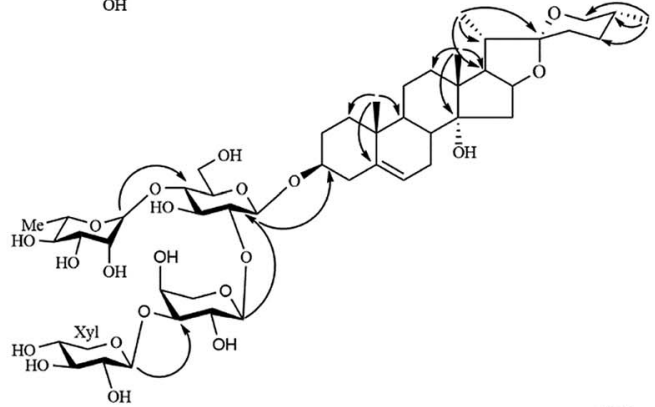

6

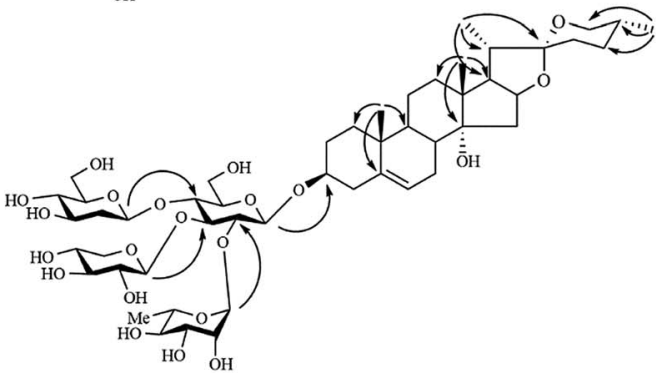

Fig. 2 Key HMBC correlations of compounds 1-6.

Table 5 Cytotoxic effects of compounds 1-7 on human cancer cells (mean $\pm S D, n=6$ )

\begin{tabular}{|c|c|c|c|}
\hline \multirow[b]{2}{*}{ Compounds } & \multicolumn{3}{|l|}{$\mathrm{IC}_{50}(\mu \mathrm{M})$} \\
\hline & HepG2 & MDA-MB-435 & A549 \\
\hline 1 & $1.69 \pm 0.18$ & $1.90 \pm 0.17$ & $4.39 \pm 0.37$ \\
\hline 2 & $\mathrm{NA}^{a}$ & $\mathrm{NA}^{a}$ & $\mathrm{NA}^{a}$ \\
\hline 3 & $-^{b}$ & $-b$ & $-b$ \\
\hline 4 & $-^{b}$ & $-^{b}$ & $-^{b}$ \\
\hline 5 & $21.18 \pm 1.87$ & $9.13 \pm 1.43$ & $21.27 \pm 2.53$ \\
\hline 6 & $\mathrm{NA}^{a}$ & $\mathrm{NA}^{a}$ & $\mathrm{NA}^{a}$ \\
\hline 7 & $\mathrm{NA}^{a}$ & $10.32 \pm 2.37$ & $29.12 \pm 4.66$ \\
\hline 5-Fluorouracil & $87.3 \pm 12.10$ & $120.5 \pm 15.53$ & $256.8 \pm 19.03$ \\
\hline
\end{tabular}

and $\delta_{\mathrm{C}} 80.7\left(\mathrm{Glc}-4^{\prime}\right)$, between $\delta_{\mathrm{H}} 4.89\left(\mathrm{~d}, J=8.0 \mathrm{~Hz}\right.$, Glc-1 $\left.{ }^{\prime}\right)$ and $\delta_{\mathrm{C}}$ 78.2 (Agly C-3) in the HMBC spectrum (Fig. 2). The structure of 6 was therefore established to be prazerigenin A-3- $O-\alpha$-L-rhamnopyranosyl-(1 $\rightarrow 2)$-[ $\beta$-D-xylopyranosyl- $(1 \rightarrow 3)]$-[ $\beta$-D-glucopyranosyl- $(1 \rightarrow 4)]$ - $\beta$-D-glucopyranoside.

All the isolates were biologically evaluated for their in vitro cytotoxic activities against MDA-MB-435, HepG2 and A549 cell lines except for compounds $\mathbf{3}$ and $\mathbf{4}$ due to insufficient amount of compounds. According to the cytotoxicity data summarized in Table 5, compound 1 exhibited the best cytotoxicity against three tested cell lines with $\mathrm{IC}_{50}$ values ranging from 1.69 to $4.39 \mu \mathrm{M}$, compounds 5 and 7 showed moderate cytotoxicity with $\mathrm{IC}_{50}$ values ranging from 9.13 to $29.12 \mu \mathrm{M}$, whereas compounds 2 and 6 were nearly inactive $\left(\mathrm{IC}_{50}>50 \mu \mathrm{M}\right)$.

\section{Experimental}

\section{General}

IR data ( $\mathrm{KBr}$ disks, in $\mathrm{cm}^{-1}$ ) were recorded on a Bruker Tensor 27 spectrometer (Bruker Corporation, Faellanden, Switzerland). Optical rotations were acquired using a JASCO P-1020 digital polarimeter (JASCO Corporation, Easton, MD, USA). NMR spectra were obtained on a Bruker Avance 500 NMR spectrometer (Bruker Corporation, Faellanden, Switzerland) using pyridine- $d_{5}$ and tetramethylsilane as solvent and internal standard, respectively. Melting points were measured on a Buchi melting point B-545 apparatus (Buchi Instrument, Switzerland) without correction. ESI-MS and HRESI-Q-TOF-MS spectroscopic data were acquired on an Agilent 1100 Series MSD Trap mass spectrometer (Agilent Technologies, Santa Clara, CA, USA) and Agilent 6520 ESI-Q-TOF spectrometer (Agilent Technologies, Santa Clara, CA, USA), respectively. D101 macroporous resin (Shaanxi Lanshen Special Resin Co., Xian, China), silica gel 
(100-200 mesh and 200-300 mesh, Qingdao Marine Chemical Factory, Qingdao, China), and C18 reversed-phase silica gel (50 mesh, YMC, Tokyo, Japan) were used for column chromatography (CC). Preparative high-performance liquid chromatography (PHPLC) experiments were performed on an Agilent 1100 Series HPLC instrument (Agilent Technologies, Santa Clara, CA, USA) equipped with an evaporative light scattering detector and a diode array detector. Fractions obtained from CC were analyzed by TLC using silica gel $\mathrm{GF}_{254}$ (Qingdao Marine Chemical Factory, Qingdao, China) plates. GC analysis was measured with an Agilent 6890 gas chromatograph (Agilent Technologies, Santa Clara, CA, USA). Standard L-rhamnose, D-xylose, L-arabinose, D-glucose, D-apiofuranose, hexamethyldisilazane, L-cysteine methyl ester hydrochloride, and trimethylchlorosilane were purchased from Sigma-Aldrich Trading Co. Ltd. (Shanghai, China).

\section{Plant material}

Dried tubers of $O$. japonicas were collected from Cixi city, Zhejiang Province, People's Republic of China, in May 2013 and authenticated by one of the authors (B. Y, Y.). A voucher specimen (no. 20130510) was deposited at the herbarium of Jiangsu Key Laboratory of TCM Evaluation and Translational Research, China Pharmaceutical University, Nanjing, People's Republic of China.

\section{Extraction and isolation}

Dried roots of $O$. japonicas $(15.5 \mathrm{~kg})$ were powdered and extracted with $75 \%$ EtOH $(1.5 \mathrm{~h}, 3 \times 60 \mathrm{~L})$, and then the solvent was removed by evaporation to afford a crude residue $(825 \mathrm{~g})$. The crude residue was suspended in $\mathrm{H}_{2} \mathrm{O}$ and then subjected to D101 macroporous resin CC, eluted successively with EtOH$\mathrm{H}_{2} \mathrm{O}(0: 100,30: 70,70: 30,95: 5, \mathrm{v} / \mathrm{v})$ to afford four subfractions (Fr. A-D). After concentration under vacuum, Fr. B and Fr. $\mathrm{C}$ were suspended in $\mathrm{H}_{2} \mathrm{O}$ and extracted successively with ethyl acetate $(10 \mathrm{~L} \times 3)$ and $n$-butyl alcohol $(10 \mathrm{~L} \times 3)$. The $n$-butyl alcohol extract of Fr. B was subjected to silica gel CC eluted with a gradient of $\mathrm{CHCl}_{3}-\mathrm{MeOH}-\mathrm{H}_{2} \mathrm{O}(90: 10: 1$ to $10: 90: 5, \mathrm{v} / \mathrm{v}$ ) to afford five sub-fractions (Fr. Ba-e). Fr. Ba was further purified using a Waters Xbridge OBD Prep C-18 column, eluted with $\mathrm{CH}_{3} \mathrm{CN}-\mathrm{H}_{2} \mathrm{O}(38: 62$, v/v) to yield compounds 2 (23 mg), 5 (9 mg), 6 (11 mg) and 7 (35 mg). The $n$-butyl alcohol part of Fr. C was subjected to silica gel CC eluted with a gradient of $\mathrm{CHCl}_{3}-\mathrm{MeOH}-\mathrm{H}_{2} \mathrm{O}(90: 10: 1$ to $30: 70: 5$, v/v) to afford Fr. $\mathrm{Ca}-\mathrm{i}$. Fr. Ca was chromatographed on an ODS column with a gradient of acetone $-\mathrm{H}_{2} \mathrm{O}(20: 80$ to $100: 0, \mathrm{v} / \mathrm{v})$ as the mobile phase to afford four sub-fractions (Fr. Ca1-4). Fr. Ca1 was further purified using a Waters Xbridge OBD Prep C-18 column, eluted with $\mathrm{CH}_{3} \mathrm{CN}-\mathrm{H}_{2} \mathrm{O}(47: 53, \mathrm{v} / \mathrm{v})$ to yield compounds 3 (12 mg) and 4 (17 mg). Compound 1 (25 mg) was obtained from Fr. Ca3 using a Waters Xbridge OBD Prep C-18 column, eluted with $\mathrm{CH}_{3} \mathrm{CN}-\mathrm{H}_{2} \mathrm{O}(50: 50, \mathrm{v} / \mathrm{v})$.

\section{Characterization of new compounds}

Compound 1. White amorphous powder; Mp 308-309 ${ }^{\circ} \mathrm{C}$; $[\alpha]_{\mathrm{D}}^{23}-85.71(c 0.10, \mathrm{MeOH})$; IR (KBr) $\nu_{\max }: 3423,2932,1057,981$,
918, 892, 836 (intensity $918<892,(25 R)$-spiroketal) $\mathrm{cm}^{-1}$; ${ }^{1} \mathrm{H}-\mathrm{NMR}$ (pyridine- $d_{5}, 500 \mathrm{MHz}$ ) data and ${ }^{13} \mathrm{C}-\mathrm{NMR}$ (pyridine- $d_{5}$, $300 \mathrm{MHz})$ data: see Tables 1-4; ESI-MS $m / z 893[\mathrm{M}+\mathrm{Na}]^{+}$; HRESI-QTOF-MS $m / z \quad 893.4447 \quad[\mathrm{M}+\mathrm{Na}]^{+}$(calcd for $\left.\mathrm{C}_{44} \mathrm{H}_{70} \mathrm{O}_{17} \mathrm{Na}, 893.4505\right)$.

Compound 2. White amorphous powder; Mp 276-277 ${ }^{\circ} \mathrm{C}$; $[\alpha]_{\mathrm{D}}^{23}-64.51$ ( c 0.10, MeOH); IR (KBr) $\nu_{\max }: 3441,2932,1048,922$, 897, 837 (intensity $922<897,(25 R)$-spiroketal) $\mathrm{cm}^{-1} ;{ }^{1} \mathrm{H}-\mathrm{NMR}$ (pyridine- $d_{5}, 500 \mathrm{MHz}$ ) data and ${ }^{13} \mathrm{C}-\mathrm{NMR}$ (pyridine- $d_{5}, 300$ MHz) data: see Tables 1-4; ESI-MS $m / z 1041$ [M + Na $]^{+}$; HRESIQTOF-MS $m / z$ 1041.4809 $[\mathrm{M}+\mathrm{Na}]^{+}$(calcd for $\mathrm{C}_{49} \mathrm{H}_{78} \mathrm{O}_{22} \mathrm{Na}$, 1041.4877).

Compound 3. White amorphous powder; $\mathrm{Mp} 279-280{ }^{\circ} \mathrm{C}$; $[\alpha]_{\mathrm{D}}^{23}-200.00(c 0.10, \mathrm{MeOH})$; IR (KBr) $\nu_{\text {max }}: 3427,2930,1045$, 978, 918, 892, 837 (intensity $918<892,(25 R)$-spiroketal) $\mathrm{cm}^{-1}$; ${ }^{1} \mathrm{H}-\mathrm{NMR}$ (pyridine- $d_{5}, 500 \mathrm{MHz}$ ) data and ${ }^{13} \mathrm{C}$-NMR (pyridine- $d_{5}$, $300 \mathrm{MHz}$ ) data: see Tables 1-4; ESI-MS $m / z 1025[\mathrm{M}+\mathrm{Na}]^{+}$; HRESI-QTOF-MS $\mathrm{m} / \mathrm{z} \quad 1025.4871[\mathrm{M}+\mathrm{Na}]^{+}$(calcd for $\left.\mathrm{C}_{49} \mathrm{H}_{78} \mathrm{O}_{21} \mathrm{Na}, 1025.4928\right)$.

Compound 4. White amorphous powder; Mp 293-294 ${ }^{\circ} \mathrm{C}$; $[\alpha]_{\mathrm{D}}^{23}-80.82$ (c 0.10, MeOH); IR (KBr) $\nu_{\max }: 3429,2925,1046$, 980, 920, 897, 839 (intensity $920<897,(25 R)$-spiroketal) $\mathrm{cm}^{-1}$; ${ }^{1} \mathrm{H}-\mathrm{NMR}$ (pyridine- $d_{5}, 500 \mathrm{MHz}$ ) data and ${ }^{13} \mathrm{C}$-NMR (pyridine- $d_{5}$, $300 \mathrm{MHz}$ ) data: see Tables 1-4; ESI-MS m/z $1025[\mathrm{M}+\mathrm{Na}]^{+}$; HRESI-QTOF-MS $m / z \quad 1025.4867 \quad[\mathrm{M}+\mathrm{Na}]^{+}$(calcd for $\left.\mathrm{C}_{49} \mathrm{H}_{78} \mathrm{O}_{21} \mathrm{Na}, 1025.4928\right)$.

Compound 5. White amorphous powder; Mp 269-270 ${ }^{\circ} \mathrm{C}$; $[\alpha]_{\mathrm{D}}^{23}-85.71$ (c 0.10, MeOH); IR (KBr) $\nu_{\max }: 3423,2930,1051$, 978, 917, 892, 836 (intensity $917<892,(25 R)$-spiroketal) $\mathrm{cm}^{-1}$; ${ }^{1} \mathrm{H}-\mathrm{NMR}$ (pyridine- $d_{5}, 500 \mathrm{MHz}$ ) data and ${ }^{13} \mathrm{C}-\mathrm{NMR}$ (pyridine- $d_{5}$, $300 \mathrm{MHz}$ ) data: see Tables 1-4; ESI-MS $m / z 1055[\mathrm{M}+\mathrm{Na}]^{+}$; HRESI-QTOF-MS $m / z \quad 1055.4968 \quad[\mathrm{M}+\mathrm{Na}]^{+}$(calcd for $\mathrm{C}_{50} \mathrm{H}_{80} \mathrm{O}_{22} \mathrm{Na}$, 1055.5033).

Compound 6. White amorphous powder; Mp 262-263 ${ }^{\circ} \mathrm{C}$; $[\alpha]_{\mathrm{D}}^{23}-166.67$ (c 0.10, MeOH); IR (KBr) $\nu_{\text {max }}: 3427,2928,1050$, 982, 922, 900, 841 (intensity $922<900,(25 R)$-spiroketal) $\mathrm{cm}^{-1}$; ${ }^{1} \mathrm{H}-\mathrm{NMR}$ (pyridine- $d_{5}, 500 \mathrm{MHz}$ ) data and ${ }^{13} \mathrm{C}-\mathrm{NMR}$ (pyridine- $d_{5}$, $300 \mathrm{MHz}$ ) data: see Tables 1-4; ESI-MS $m / z 1055[\mathrm{M}+\mathrm{Na}]^{+}$; HRESI-QTOF-MS $m / z \quad 1055.4977[\mathrm{M}+\mathrm{H}]^{+}$(calcd for $\left.\mathrm{C}_{50} \mathrm{H}_{80} \mathrm{O}_{22} \mathrm{Na}, 1055.5033\right)$.

\section{Acid hydrolysis}

Compounds 1-6 (2 $\mathrm{mg}$ each) were individually refluxed with $2 \mathrm{~mL}$ of $2 \mathrm{M} \mathrm{HCl}\left(\mathrm{HCl}-\mathrm{H}_{2} \mathrm{O}\right.$-dioxane, $\left.1: 2: 3\right)$ at $95{ }^{\circ} \mathrm{C}$ for $4 \mathrm{~h}$ in a water bath and then dioxane was removed by evaporation. Each solution was then diluted with $\mathrm{H}_{2} \mathrm{O}(2 \mathrm{~mL})$ and further extracted with EtOAc $(2 \mathrm{~mL})$, with the aqueous layer repeatedly evaporated until a neutral residue was obtained (10-15 times). The residue was then analyzed by TLC over silica gel together with authentic sugar samples using EtOAc-pyridine-absolute EtOH- $\mathrm{H}_{2} \mathrm{O}$ (8:1:1:2) and aniline-diphenylamine-phosphoric acid (5:5:1) as developing solution and detection solution, respectively. The remaining residue in pyridine (300 $\mu \mathrm{L}$ ) was mixed with L-cysteine methyl ester hydrochloride (4 mg) and then heated at $60{ }^{\circ} \mathrm{C}$ in an oil bath for $1.5 \mathrm{~h}$. Then $300 \mu \mathrm{L}$ of hexamethyldisilazane-trimethylchlorosilane $(2: 1)$ was added 
and the mixture was kept at $60{ }^{\circ} \mathrm{C}$ for a further $30 \mathrm{~min}$. After centrifugation, the supernatant was analyzed by GC under the following conditions: capillary column, HP-5 $(0.32 \mathrm{~mm} \times 30 \mathrm{~m}$ $\times 0.5 \mu \mathrm{m})$; flame ionization detection; detector temperature, $280{ }^{\circ} \mathrm{C}$; injection temperature, $250{ }^{\circ} \mathrm{C}$; initial temperature, $150{ }^{\circ} \mathrm{C}$ and an initial time of $5 \mathrm{~min}, 1.1^{\circ} \mathrm{C} \mathrm{min}{ }^{-1}$ to $260{ }^{\circ} \mathrm{C}$ and then held for $10 \mathrm{~min}$; carrier, $\mathrm{N}_{2}$; split ratio, $1 / 25$. The monosaccharides of compound $\mathbf{1}$ were identified as D-glucose, L-rhamnose and D-apiofuranose by comparing the retention times $\left(T_{\mathrm{R}}\right)$ of monosaccharide derivatives with the derivatives prepared in the same procedure from standard sugars. Similarly, D-glucose, D-xylose, L-rhamnose and L-arabinose were identified from compounds 2, 3 and 4, D-glucose, D-xylose and L-rhamnose were identified from compounds $\mathbf{5}$ and $\mathbf{6}$.

\section{Cytotoxicity assay}

The in vitro cytotoxic activities of the isolates against MDA-MB435, HepG2 and A549 cell lines were measured by the 3-(4,5dimethylthiazol-2-yl)-2,5-diphenyltetrazolium bromide (MTT) assay as described in the literature ${ }^{32}$ and 5-fluorouracil was used as positive control. All cells lines were purchased from the Cell Bank of the Shanghai Institute of Chinese Academy of Sciences and incubated at $37{ }^{\circ} \mathrm{C}$ in a humidified atmosphere of $95 \%$ air and $5 \% \mathrm{CO}_{2}$, with high glucose DMEM medium (Gibco, Grand Island, NY, USA) containing 10\% fetal bovine serum (Life Technologies Corporation, Carlsbad, CA, USA) used as culture medium. The cells in logarithmic phase were seeded in 96-well plates for $12 \mathrm{~h}$, then the medium was replaced by fresh medium containing test compounds at various concentrations and treated for an additional $48 \mathrm{~h}$. At the end of the treatment period, the medium was replaced by $100 \mu \mathrm{L}$ of fresh medium containing $0.5 \mathrm{mg} \mathrm{mL} \mathrm{mL}^{-1}$ MT and the cells were cultured for a further $3 \mathrm{~h}$. The medium solution was then removed and $150 \mu \mathrm{L}$ of DMSO was added to dissolve the MTT reduction product (formazan crystals). The optical density was measured by detection of the absorbance at $570 \mathrm{~nm}$ and reference wavelength of $650 \mathrm{~nm}$ on a microplate reader.

\section{Conclusions}

Steroidal constituents exhibit various biological activities due to diversity of their chemical structures. The clear antitumorigenic properties of steroidal constituents have attracted the attention of pharmaceutical researchers for the development of anticancer drugs. In this work, six new steroidal saponins (1-6) and one known steroidal saponin (7) were obtained and characterized from the root of $O$. japonicas. Cytotoxicity data of these compounds against MDA-MB-435, HepG2 and A549 cancer cell lines in vitro indicated that compound 1 exhibited significant cytotoxicity with $\mathrm{IC}_{50}$ values ranging from 1.69 to $4.39 \mu \mathrm{M}$, compounds 5 and 7 showed moderate cytotoxicity with $\mathrm{IC}_{50}$ values ranging from 9.13 to $29.12 \mu \mathrm{M}$. These compounds may have a possibility for use in anticancer drug development.

\section{Conflicts of interest}

There are no conflicts to declare.

\section{Acknowledgements}

This research was funded by the National Natural Science Foundation of China (No. 81473317 and 81673555), the Major National Science and Technology Project of China for Significant New Drugs Development (No. 2012ZX09102201-015), Qing Lan Project, the Priority Academic Program Development of Jiangsu Higher Education Institutions, the 2011' Program for Excellent Scientific and Technological Innovation Team of Jiangsu Higher Education, and the Major Project Program of State Key Laboratory of Natural Medicines, China Pharmaceutical University (No. SKLNMZZ201203).

\section{Notes and references}

1 Editorial Committee of Flora of China, Flora of China, Science Press, Beijing, 2014.

2 National Pharmacopoeia Committee, Pharmacopoeia of Peoples Republic of China 2015, Part 1, China Medical Science Press, Beijing, 2015.

3 X. Lu, W. Tong, S. Wang, J. Li, J. Zheng and X. Fan, J. Pharm. Biomed. Anal., 2016, 134, 60-70.

4 Y. Wang, Y. Zhu, K. Ruan, H. Wei and Y. Feng, Carbohydr. Polym., 2014, 114, 183-189.

5 M. Zhao, W. F. Xu, H. Y. Shen, P. Q. Shen, J. Zhang and D. D. Wang, J. Pharm. Biomed. Anal., 2017, 138, 134.

6 Y. L. Zhang, M. Z. Xi, Y. B. Choi and B. H. Lee, J. Med. Food, 2017, 20, 637-645.

7 J. Chen, J. Yuan, L. Zhou, M. Zhu, Z. Shi, J. Song, Q. Xu, G. Yin, Y. Lv, Y. Luo, X. Jia and L. Feng, Biomed. Pharmacother., 2017, 87, 118-126.

8 A. Tada, R. Kasai, T. Saitoh and J. Shoji, Chem. Pharm. Bull., 1980, 28, 2039-2044.

9 A. Tada, R. Kasai, T. Saitoh and J. Shoji, Chem. Pharm. Bull., 1980, 28, 1477-1484.

10 J. M. Chang, C. C. Shen, Y. L. Huang, M. Y. Chien, J. C. Ou, B. J. Shieh and C. C. Chen, J. Nat. Prod., 2002, 65, 1731-1733.

11 N. Li, J. Y. Zhang, K. W. Zeng, L. Zhang, Y. Y. Che and P. F. Tu, Fitoterapia, 2012, 83, 1042-1045.

12 C. L. Duan, Z. Y. Kang, C. R. Lin, Y. Jiang, J. X. Liu and P. F. Tu, J. Asian Nat. Prod. Res., 2009, 11, 876-879.

13 C. Zhou, L. Zou, J. Mo, X. Wang, B. Yang and Q. He, Helv. Chim. Acta, 2013, 96, 1397-1405.

14 Z. Iqbal, S. Isojima, A. Noda and Y. Fujii, J. Weed Sci. Technol., 2003, 47, 160-161.

15 C. Jiang, Z. H. Liu, L. Li, B. B. Lin, F. Yang and M. J. Qin, J. Asian Nat. Prod. Res., 2012, 14, 491-495.

16 C. L. Duan, Y. Jiang, Y. Jiang, C. R. Lin, J. X. Liu and P. F. Tu, J. Chin. Pharm. Sci., 2009, 18, 236-239.

17 M. Tomoda and S. Kato, Jpn. J. Pharmacogn., 1966, 20, 6-9.

18 M. Tomoda and S. Kato, Chem. Pharm. Bull., 1968, 16, 113116. 
19 N. Li, L. Zhang, K. W. Zeng, Y. Zhou, J. Y. Zhang, Y. Y. Che and P. F. Tu, Steroids, 2013, 78, 1-7.

20 C. L. Duan, Y. J. Li, P. Li, Y. Jiang, J. X. Liu and P. F. Tu, Helv. Chim. Acta, 2010, 93, 227-232.

21 J. Qi, Z. F. Hu, Y. F. Zhou, Y. J. Hu and B. Y. Yu, Chem. Pharm. Bull., 2015, 63, 187-194.

22 Z. H. Cheng, T. Wu and B. Y. Yu, J. Asian Nat. Prod. Res., 2006, 8, 555-559.

23 Y. F. Zhou, J. Qi, D. N. Zhu and B. Y. Yu, Chin. Chem. Lett., 2008, 19, 1086-1088.

24 M. Kuroda, Y. Mimaki, K. Ori, H. Sakagami and Y. Sashida, J. Nat. Prod., 2004, 67, 1690-1696.

25 L. Tang, Z. Wang, H. Wu, A. Yokosuka and Y. Mimaki, Phytochemistry, 2014, 107, 102-110.
26 J. Z. Wang, L. M. Ye and X. B. Chen, Chin. Chem. Lett., 2008, 19, 82-84.

27 M. A. Fernandez-Herrera, M. G. Hernandez-Linares, G. Guerrero-Luna, S. Meza-Reyes, S. Montiel-Smith and J. Sandoval-Ramirez, Lett. Org. Chem., 2011, 8, 341-346.

28 K. W. Wang, H. Zhang, L. Q. Shen and W. Wang, Carbohydr. Res., 2011, 346, 253-258.

29 J. J. Chen, Z. L. Zhu and S. D. Luo, Acta Bot. Yunnanica, 2000, 22, 97-102.

30 X. Zhou, X. He, G. Wang, H. Gao, G. Zhou, W. Ye and X. Yao, J. Nat. Prod., 2006, 69, 1158-1163.

31 M. Sugiyama, K. Nakano, T. Tomimatsu and T. Nohara, Chem. Pharm. Bull., 2008, 32, 1365-1372.

32 Y. Wu, X. M. Wang, S. X. Bi, W. Zhang, R. M. Li, R. J. Wang, B. Y. Yu and J. Qi, RSC Adv., 2017, 7, 13696-13706. 